\title{
Wpływ rozwoju nowoczesnych technologii na proces stanowienia prawa w Polsce i wybranych państwach Unii Europejskiej $^{1}$
}

\begin{abstract}
Wpływ najnowszych technologii na proces stanowienia prawa jest niewątpliwy i wraz z postępującym upowszechnianiem się fenomenów technologicznych (sztucznej inteligencji, internetu rzeczy, Big Data) staje się coraz większy. Ważne jest, aby to przepisy adaptowały się do naturalnych zachowań w społeczeństwie informacyjnym, nie zaś odwrotnie. Rozwój nowoczesnych technologii przyczynia się do zmiany dotychczasowych modeli biznesowych oraz zachowań konsumenckich - m.in. projekt dyrektywy w sprawie praw autorskich na jednolitym rynku cyfrowym dowodzi trudności w prawnym regulowaniu tych zjawisk. Przykład regulacji statusu prawnego danych maszynowych dowodzi natomiast, że ustanowienie kolejnego prawa wyłącznego może mieć fatalne skutki dla innowacyjności.
\end{abstract}

Słowa kluczowe: innowacyjność, technologia, Unia Europejska

Influence of the modern technologies development on the lawmaking process in Poland and other European Union countries: The influence of the latest technologies on the lawmaking process is undoubtedly significant and with the growing popularity of technological phenomena (artificial intelligence, the Internet of Things, Big Data) it is becoming larger. It is important that rules adapt to natural behavior in the information society, and not vice versa. The development of modern technologies contributes to changing existing business models and consumer behavior - inter alia the draft directive on copyright in the digital single market indicates difficulties concerning legal regulating of these phenomena. On the other hand an example of regulating legal status of machine datashows that the establishment of another exclusive right can have disastrous consequences for innovation.

Keywords: innovation, technology, European Union

Doktor nauk prawnych, LL.M., radca prawny - daflisak@yahoo.de • https://orcid.org/0000-0002-0805-5685

Tradycja nie jest hamulcem postępu, lecz konieczna jego podstawa, pomostem między tym, co byto, a tym, co jest $i$ co się aktualnie dzieje, jest transmisja między osiagnięciami myśli i praktyki dawnych generacji a zdobyczami generacji nowych.

M. Sawczuk ${ }^{2}$

1 Ekspertyza na temat: Rozwój nowoczesnych technologii w kontekście procesu stanowienia prawa w Polsce i wybranych państwach Unii Europejskiej sporządzona 26 kwietnia 2019 r. na zlecenie przewodniczącego Komisji Cyfryzacji, Innowacyjności i Nowoczesnych Technologii; BAS 505/19.

2 M. Sawczuk, Tradycja a postęp [w:] Ewolucja polskiego postępowania cywilnego wobec przemian politycznych, społecznych i gospodarczych, red. H. Dolecki, K. Flaga-Gieruszyńska, Warszawa 2008, s. 18. 


\section{Uwagi wprowadzające}

Poza sporem powinna pozostawać teza, że nowoczesne technologie powiązane ze zjawiskiem cyfrowej transformacji (ang. digital transformation) społeczeństwa mają wpływ na absolutnie każdy obszar ludzkiej egzystencji, nie wyłączając obszaru prawa. Najnowsze technologie są niezbędnym filarem rozwoju gospodarczego, mogą przyczyniać się do wzrostu konkurencyjności, posiadać wartość prodemokratyczną, prokonsumencką, ułatwiać dostęp do służby ochrony zdrowia, służyć powszechnemu bezpieczeństwu, rozwijać usługi telekomunikacyjne, informatyczne - lista obszarów pozostających w permanentnej interakcji z najnowszymi technologiami jest praktycznie nieograniczona. W istocie rozwój internetu już spowodował przestawienie na gospodarkę elektroniczną, czyli taką, w której: produkty oraz usługi sa wykorzystywane powszechnie, bez ograniczeń terytorialnych ${ }^{3}$.

Obok szans związanych z ekspansją technologiczną istnieją również liczne zagrożenia. Do najczęściej wymienianych należą: ryzyko nadmiernej inwigilacji społeczeństwa ${ }^{4}$, wielopłaszczyznowe zagrożenia prawa do prywatności ${ }^{5}, z a-$ grożenia wynikające z istnienia zdematerializowanej cyberprzestrzeni (phishing, spamming, kradzież tożsamości, sniffing, pornografia dziecięca, mowa nienawiści, deep fakes - to tylko wybrane przykłady zagrożeń). Można wreszcie wskazać zagrożenia o charakterze ogólnospołecznym, takie jak wykluczenie cyfrowe, luka cyfrowa (albo podział cyfrowy, digital divide), przestępczość komputerowa.

Być może najciekawszym przykładem powiązania szans i zagrożeń z najnowszą technologią są kryptowaluty, w tym najpopularniejsza - bitcoin. Choć waluta ta niedawno obchodziła 10 -lecie swojego istnienia ${ }^{6}$, w tym okresie doszło już

3 K. Chałubińska-Jentkiewicz, M. Karpiuk, Prawo nowych technologii, cz. I, rozdz. I, 2015, LEX.

4 Aktualnym przykładem w tym zakresie jest sytuacja w Chinach, gdzie od $2016 \mathrm{r}$. wprowadzono system „scoringu” obywateli (oceny zachowań). Przykładowo, spóźnienie ze spłatą raty kredytu czy nawiązanie kontaktów z „niepożądaną” osobą mogą mieć wpływ na późniejszą możliwość podróżowania po kraju czy zaciągnięcia kredytu w banku, zob. T.F. Chan, System oceny obywateli $w$ Chinach powstrzymał już ludzi od $11 \mathrm{mln}$ lotów i $4 \mathrm{mln}$ podróży pociagiem, https://businessinsider.com.pl/lifestyle/podroze/system-oceny-obywateli-w-chinach-efekty-dzialania/7yl1phz [dostęp 25 kwietnia 2019 r.].

5 Dla przykładu, każde korzystanie z zasobów internetowych pozostawia ślad (tzw. digital footprint) możliwy do identyfikacji. Świadomość, że „internet nie zapomina”, może prowadzić do „efektu mrożącego” (chilling effect) polegającego na nadmiernej wstrzemięźliwości internautów w wypowiadaniu jakichkolwiek uwag, zajmowaniu stanowisk w środowisku internetowym.

6 D. Osowski, Historia bitcoina. Kryptowaluta świętuje 10. urodziny, „Parkiet” z 31 października 2018 r., https://www.parkiet.com/Kryptowaluty/310319905-Historia-bitcoina-Kryptowaluta-swietuje-10-urodziny.html [dostęp 25 kwietnia 2019 r.]. 
do licznych sukcesów i dramatów inwestujących w bitcoina. Mimo że jeszcze w grudniu 2018 r. jednostka tej waluty była warta niemal 20 tys. dolarów, jej cena kilka miesięcy później dryfuje w okolice $1 / 3$ tej wartości.

Warto jedynie krótko podkreślić, że technologia sama w sobie wymyka się ocenom etycznym: nigdy nie jest ona ani zła, ani dobra. Kluczowy w tej mierze jest natomiast sposób jej wykorzystania ${ }^{7}$. Jednocześnie istotną zasadą obowiązującą w procesie stanowienia prawa jest zasada neutralności technologicznej. Oznacza ona zakaz preferowania określonej technologii w celu utrzymania konkurencyjności rynku oraz stoi na przeszkodzie budowaniu przepisów opartych na działaniu określonej technologii lub w ogóle z wykorzystaniem nazewnictwa właściwego dla określonej technologii, w tym słowa „internet”.

\section{Dookreślenie tematu}

Powiązanie rozwoju najnowszych technologii z procesem stanowienia prawa może być przedmiotem analizy na wielu płaszczyznach. W niniejszej opinii przyjęto dwie perspektywy. Jedna z nich, bardziej konkretna, dotyczy wpływu rozwoju technologii na stosowanie prawa na przykładzie postępowań cywilnych. Druga perspektywa dotyczy etapu wcześniejszego: wpływu najnowszych technologii, których emblematycznym przykładem są prace nad rozwojem tzw. sztucznej inteligencji (Artificial Intelligence), na proces stanowienia prawa i obieranie określonych kierunków legislacyjnych. Doskonałym przykładem w tym zakresie są zmiany w obszarze prawa własności intelektualnej, w tym najnowszy przykład w postaci dyrektywy w sprawie praw autorskich na jednolitym rynku cyfrowym. Innym przykładem jest zagadnienie regulacji prawnego statusu danych maszynowych - paliwa XXI wieku.

\section{Rola postępu technicznego w procesie stanowienia prawa}

Chociaż tytuł opinii mógłby sugerować, że to nowe technologie rozwijają się wraz z rozwojem prawa, wniosek taki byłby chybiony. Jest albo inaczej - powin-

7 [...] to, co wiemy na pewno, to to, że technologia nigdy nie jest dobra, ani zła. Ważne jest, co my z nia robimy - słowa M. Benioffa, CEO Salesforce, za: M. Bellon, Szef technologicznego giganta: AI podzieli świat. Społeczeństwa bez niej będą biedniejsze i słabsze, https://businessinsider.com.pl/technologie/marc-benioff-ceo-salesforce-o-sztucznej-inteligencji/zx4tq1m [dostęp 25 kwietnia 2019 r.].

8 Na przykład, zasadzie neutralności technologicznej hołduje art. 20 RODO (rozporządzenie 2016/679 z 27 kwietnia 2016 r.), które przewiduje prawo do przenoszenia danych osobowych (data portability). Wedle tego przepisu: osoba, której dane dotycza, ma prawo otrzymać $w$ ustrukturyzowanym, powszechnie używanym formacie nadajacym się do odczytu maszynowego dane osobowe. 
no być - zupełnie odwrotnie. To przepisy prawa usiłują nadążyć za naturalnymi zachowaniami uczestników rynku związanymi z korzystaniem z dobrodziejstw społeczeństwa informacyjnego.

Bodaj najlepszym przykładem zmagań prawodawcy z nadążeniem za rozwojem technicznym jest obszar własności intelektualnej, zwłaszcza prawo autorskie. O czym będzie jeszcze mowa, na przykładzie prawa autorskiego doskonale widać, jak istotne dla wprowadzenia jakichkolwiek nowych przepisów prawa (np. zupełnie nowego uprawnienia o charakterze wyłącznym, tj. wykluczającym podmioty trzecie z możliwości korzystania z określonego dobra), jest uprzednia weryfikacja, czy takie działanie ustawodawcy jest absolutnie niezbędne z punktu widzenia funkcjonowania rynku. Innymi słowy, potrzeba interwencji ustawodawcy powstaje jedynie wówczas, kiedy zawodzi mechanizm samoregulacji rynku.

Trzeba sobie uświadomić, że postęp techniczny nie powstaje w wyniku mnożenia kolejnych regulacji prawnych, a jedynie dzięki istnieniu konkurencji rynkowej, która zmusza do poszukiwania innowacyjnych rozwiązań. Nowe prawo powinno się pojawić jedynie wówczas, kiedy naruszone są zasady uczciwego konkurowania wskutek przedwczesnego pojawienia się na rynku naśladowców nowatorskiego rozwiązania, zanim zostanie zamortyzowana inwestycja w rozwiązanie. $\mathrm{W}$ istocie prawa ochronne mają przecież za zadanie chronić przez określony czas wyłączność pierwszego podmiotu na rynku (first mover advantage). Kiedy prawo ochronne powstanie jednak zbyt wcześnie, materializuje się ryzyko „zduszenia” konkurencji, w efekcie czego również pozostaje brak zachęt do inwestowania w postęp technologiczny9.

Na obszarze prawa autorskiego znane są dość liczne przykłady legislacyjnych "falstartów", kiedy to wprowadzono nowe uprawnienia, które zdecydowanie nie przyniosły oczekiwanych, pozytywnych rezultatów w postaci utrzymania konkurencyjności rynku ${ }^{10}$. Warto wskazać, że istnieją przykłady wydarzeń, które są

$9 \quad[. .$.$] Hinzu kommt der weit verbreitete Irrtum, Fortschritt entstehe dank solcher Schut-$ zrechte. Tatsächlich ist es vor allem der Druck des Wettbewerbs, der zu innovativen Lösungen führt [...] [dochodzi do tego rozpowszechnione, ale błędne przekonanie, że postęp jest konsekwencja tego rodzaju praw ochronnych. W rzeczywistości wynika on jednak $z$ istnienia konkurencji, która prowadzi do innowacyjności - tłum. autora opinii] - R. Hilty, Eine neue Kultur, „Süddeutsche Zeitung” z 20 marca 2019 r.

10 Dość zgodnie ocenia się, że nie spełniła pokładanych w niej nadziej dyrektywa 96/6 o ochronie baz danych - zob. oceny skutków jej obowiązywania przez okres 20 lat: [...] the Directive has been quite effective in harmonising database protection in Europe, but there is no evidence to conclude that the sui generis right has been fully effective in stimulating investment in the European database industry, nor in creating a fully functioning access regim [dyrektywa okazała się sukcesem, jeśli idzie o efektywną harmonizacje ochrony baz danych $w$ Europie, ale brak podstaw, żeby twierdzić, iż stworzone prawo sui generis okazało się efektywne, jeśli chodzi o stymulację inwestycji w europejski przemyst bazodanowy bądź o stworzenie $w$ pełni funkcjonalnych zasad dostępu - tłum. autora 
z sukcesem komercjalizowane i to bez istnienia szczególnego prawa ochronnego. Należą do nich choćby widowiska sportowe, które zgodnie z wiedzą powszechną są komercjalizowane w atrakcyjnej postaci jako jeden „produkt”, i to bez istnienia odrębnego prawa, które chroniłoby je w całości (takie prawo do widowiska sportowego, określane również jako „prawo stadionu”, istnieje jednak w Brazylii czy we Francji).

\section{Dane maszynowe}

\section{Znaczenie danych}

Dalszy rozwój technologiczny jest uwarunkowany dostępem do możliwie największej ilości danych. Nie budzi najmniejszych wątpliwości, że to dane są podstawowym motorem napędowym wszelkich zjawisk technologicznych, które zwykło się identyfikować z postępem cywilizacyjnym. Należą do nich fenomen sztucznej inteligencji (Artificial Intelligence, AI), internet rzeczy (Internet of Things, IoT ${ }^{11}$ ) czy wielkie zbiory danych (Big Data ${ }^{12}$ ). Poniżej przedstawiono alegoryczne znaczenie danych.

Okładka „The Economist” (zob. rysunek 1, s. 199) przedstawia hegemonów dzisiejszego świata w postaci sześciu wiodących spółek amerykańskich z branży szeroko rozumianych nowych technologii, które przedstawione jako platformy wiertnicze zostały posadowione na złożach ropy naftowej. Z okładki wynika, że swoje istnienie oraz możliwość dalszego rozwoju zawdzięczają one właśnie olbrzymim zasobom danych, z których obficie czerpią.

Dane są niezbędne przede wszystkim dla dalszego rozwoju prac nad sztuczną inteligencją, którą należy rozumieć nie tyle przez pryzmat filmowych, człekokształtnych cyborgów, ile zaawansowanych systemów informatycznych wyposażonych w zdolność do uczenia (uczenie maszynowe, machine learning) właśnie dzięki przetwarzaniu możliwie największych zasobów danych. Stopniowe upo-

opinii] - Commission Staff Working Document, Evaluation of Directive 96/9/EC, SWD(2018) 147 final, https://ec.europa.eu/digital-single-market/en/news/staff-working-document-and-executive-summary-evaluation-directive-969ec-legal-protection.

11 Koncepcja, wedle której jednoznacznie identyfikowalne przedmioty moga pośrednio albo bezpośrednio gromadzić, przetwarzać lub wymieniać dane za pośrednictwem [...] sieci komputerowej. Do tego typu przedmiotów zaliczają się między innymi urządzenia gospodarstwa domowego, artykuly oświetleniowe i grzewcze oraz urządzenia noszone (wearables) - Wikipedia, https://pl.wikipedia.org/wiki/Internet_rzeczy [dostęp 25 kwietnia 2019 r.].

12 Termin odnoszący się do dużych, zmiennych i różnorodnych zbiorów danych, których przetwarzanie i analiza jest trudna, ale jednocześnie wartościowa, ponieważ może prowadzić do zdobycia nowej wiedzy. Pojęcie dużego zbioru danych jest względne i oznacza sytuacje, gdy zbioru nie da się przetwarzać przy użyciu trywialnych, powszechnie dostępnych metod, Wikipedia, https://pl.wikipedia.org/wiki/Big_data [dostęp 25 kwietnia 2019 r.]. 


\section{Rysunek 1. Okładka „The Economist" z 6 maja 2017 r. z podpisem: The world's most} valuable resource is no longer oil, but data [najbardziej wartościowym surowcem na świecie nie jest już ropa naftowa, lecz dane - tłum. autora])

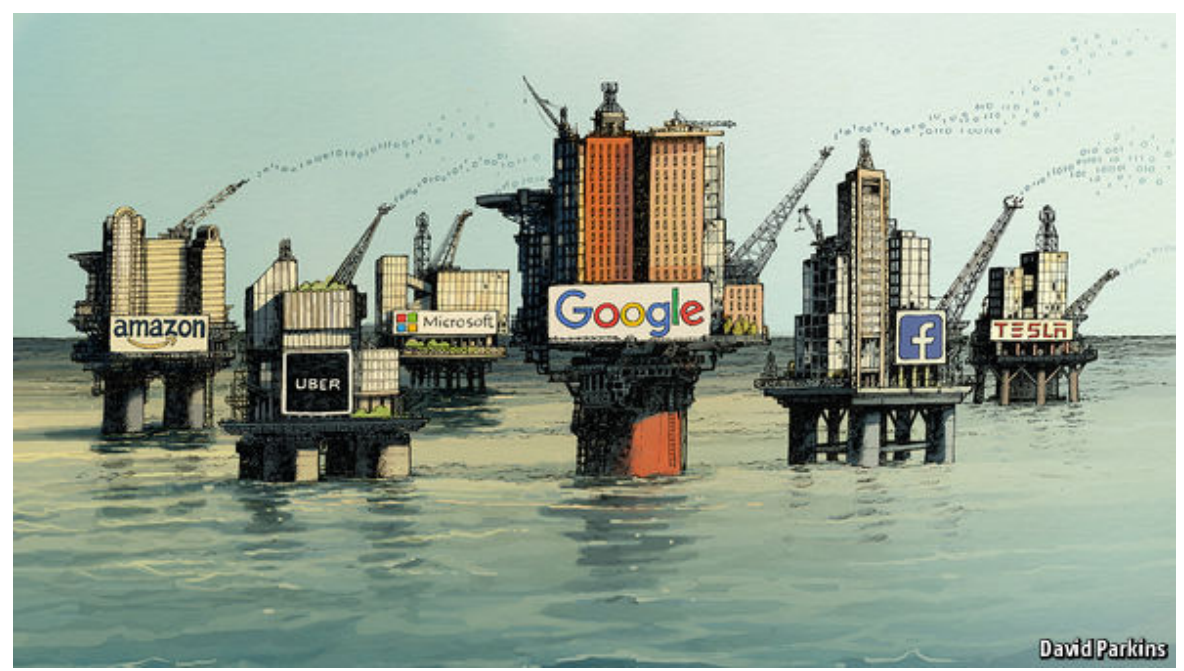

\section{Rysunek 2. Fale Schumpetera}

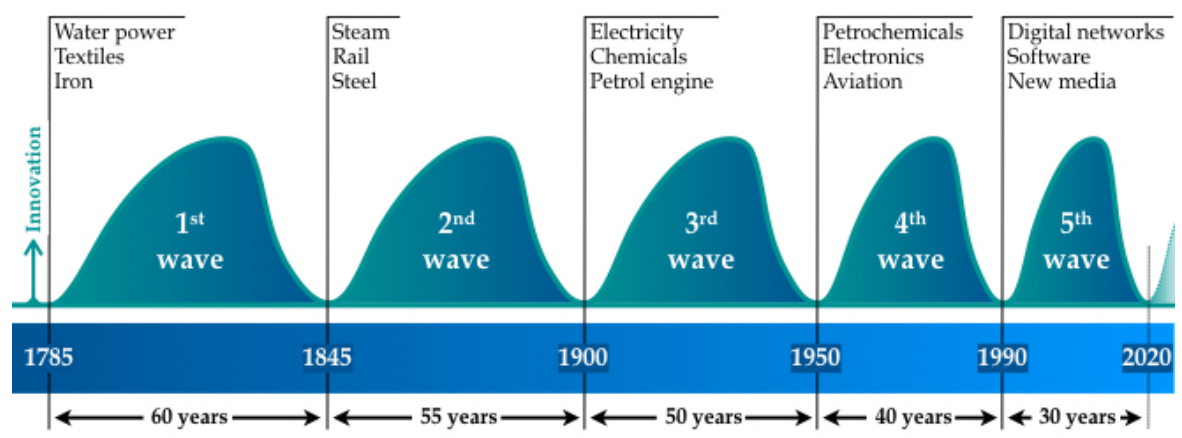

wszechnienie AI należy wiązać również z możliwością analiz olbrzymich, złożonych nawet z miliardowych ilości rekordów baz danych (Big Data) ${ }^{13}$.

Warto $\mathrm{w}$ tym miejscu jedynie zasygnalizować, że zgodnie z przebiegiem tzw. fal Schumpetera (rysunek 2) znajdujemy się obecnie u schyłku ery „tradycyjnej”

13 M. Rojszczak, Prawne aspekty systemów sztucznej inteligencji - zarys problemu [w:] Sztuczna inteligencja, blockchain, cyberbezpieczeństwo oraz dane osobowe, red. K. Flaga-Gieruszyńska, J. Gołaczyński, D. Szostek, Warszawa 2019, s. 3 i nast. 
cyfryzacji, w którym podstawowym motorem napędowym są komputerowe sieci cyfrowe oraz internet (zob. piątą falę). Kolejnym etapem rozwoju postępu cywilizacyjnego będą systemy maszynowe wyposażone w zdolność autoedukacji.

$\mathrm{Z}$ tego też punktu widzenia bodaj najistotniejszym zagadnieniem wiążącym rozwój technologiczny z procesem stanowienia prawa jest pytanie o prawny status danych.

\section{Prawny status danych}

Z uwagi na trudną do przeszacowania wartość danych pojawia się naturalne pytanie, czyją własnością powinny być dobra o tak doniosłym znaczeniu? Jeden z unijnych komisarzy, Günther Oettinger, szczególnie intensywnie opowiadał się za stworzeniem podobnego do prawa własności „prawa do korzystania $\mathrm{z}$ danych” (data use right $)^{14}$. Jeszcze w 2017 r. można było przeczytać komunikaty Komisji Europejskiej, w których opowiadała się ona za stworzeniem pojęcia „producenta danych” (data producer), któremu miałoby przysługiwać prawo „własności” danych ${ }^{15}$. Dopiero wskutek zdecydowanej krytyki ze strony przedstawicieli prawa oraz ekonomii zrezygnowano z próby regulacji własności danych na wzór prawa własności ${ }^{16}$.

Już na wstępie warto zadać pytanie, czy w ogóle istnieje potrzeba wprowadzenia nowej regulacji. Zgodnie z wywiedzionym wcześniej wnioskiem potrzeba interwencji ustawodawczej pojawia się - co do zasady - dopiero wówczas, gdy brak nowego prawa powoduje powstanie zaburzeń na rynku. Sygnały w tym zakresie powinni wysyłać sami uczestnicy rynku. I tak z jednej strony, skonstruowanie w latach 60. ubiegłego wieku prawa do nagrań (tzw. fonogramów, czyli utrwaleń dźwięków) wynikało z potrzeby ochrony nakładów producentów nośników dźwięku - płyt winylowych, kaset magnetofonowych etc. Brak przyznania ustawowego monopolu na korzystanie z utrwaleń muzyki mógłby oznaczać

14 B. Hugenholtz, Data Property: Unwelcome Guest in the House of IP, https://www.ivir. nl/publicaties/download/Data_property_Muenster.pdf [dostęp 25 kwietnia 2019 r.]; zob. też głos zdecydowanego sprzeciwu europosłanki J. Redy: No „copyright” on raw data!, juliareda.eu/2017/01/no-copyright-on-raw-data [dostęp 25 kwietnia 2019 r.].

15 Komunikat Komisji, „Budowa europejskiej gospodarki opartej na danych”, $\operatorname{COM(2017)} 09$ final, 10 stycznia 2017 r., s. 13.

16 Punktem wyjścia powinno być zapewnienie, aby rynki danych miały możliwie najlepsze warunki do samodzielnego rozwoju [...] Zasadniczo przedsiębiorstwa powinny mieć swobodę decydowania o tym, komu i na jakich warunkach można przyznać dostęp do posiadanych przez nie danych nieosobowych. Ogólnie rzecz biorą, zainteresowane strony nie popieraja również nowego rodzaju prawa własności danych, a z szeregu przekazanych opinii wynika, że kluczowa kwestia w wymianie danych między przedsiębiorstwami jest nie tyle własność, co sposób organizacji dostępu do danych, komunikat Komisji, „W kierunku wspólnej europejskiej przestrzeni danych”, COM(2018) 232 final, s. 11. 
brak możliwości amortyzacji kosztów związanych z inwestowaniem w coraz to nowe technologie oraz - generalnie rzecz ujmując - brak zachęt dla uczestnictwa $\mathrm{w}$ postępie technologicznym. $\mathrm{Z}$ drugiej strony, właśnie $\mathrm{w}$ tym samym czasie, tj. $\mathrm{w}$ latach 60. ubiegłego wieku, wraz $\mathrm{z}$ upowszechnieniem się domowych metod zwielokrotniania nośników z muzyką dostrzeżono potrzebę zagwarantowania „Zwykłym” użytkownikom prawa do takiego zwielokrotniania na tzw. użytek prywatny, czyli wykluczający przede wszystkim kopiowanie masowe lub czynione w celach komercyjnych.

W przypadku regulacji danych tego rodzaju „wołania” ze strony rynku próżno nasłuchiwać. Można twierdzić nawet więcej. Powstały specjalistyczne opracowania w tym zakresie, czy to ekonomiczne ${ }^{17}$ czy też prawnicze ${ }^{18}$, które jednoznacznie wskazują, że stworzenie nowego reżimu ochronnego dla danych jest - przynajmniej na obecnym etapie rozwoju gospodarczego oraz obecnym stopniu rozpoznania znaczenia danych dla gospodarki - niezasadne. Stworzenie nowego prawa wymagałoby dookreślenia podstawowych parametrów nowej regulacji, do których należy ustalenie: podmiotu ochrony (kto jest właścicielem danej), przedmiotu ochrony (czy dana podlega na płaszczyźnie semantycznej - znaczeniowej, czy też syntaktycznej - zapisanych znaków), zakresu prawa (wyznaczenie granic pozytywnych, tj. tego, do czego podmiot uprawniony miałby mieć wyłączną kompetencję, oraz sfery negatywnej, tj. zakresu obrony przed zachowaniami naruszycielskimi) czy wreszcie - czasu ochrony (czy powinien on być liczony w latach lub miesiącach czy w znacznie mniejszych okresach, np. dniach ${ }^{19}$ ).

Wśród argumentów generalnej natury podnoszony jest przede wszystkim ten, że kreowanie kolejnego prawa o charakterze wyłącznym nie jest niezbędne, aby stworzyć „zachętę" (incentive) do tworzenia i analizowania nowych danych. Ilość danych będzie się zwiększać wykładniczo, niezależnie od naszej woli, a często i wiedzy. Wzbogacenie porządku prawnego o kolejny reżim ochronny tworzy ryzyko negatywnego wpływu na pożądane ze wszech miar zjawiska konkurencyjności i innowacyjności, jako że sukces gospodarki opartej na danych (ang. data

17 Zob. np. W. Kerber, A New (Intellectual) Property Right for Non-Personal Data? An Economic Analysis, https://papers.ssrn.com/sol3/papers.cfm?abstract_id=2858171 [dostęp 25 kwietnia 2019 r.].

18 Zob. np. P.K. Yu, Data Producer's Right and the Protection of Machine-Generated Data, "Tulane Law Review" 2019, Vol. 93, https://papers.ssrn.com/sol3/papers.cfm?abstract_ id=3271189\&download=yes [dostęp 25 kwietnia 2019 r.]; B. Hugenholtz, Data Property, op. cit.

19 W przypadku liczenia okresu ochrony w dniach, ewentualnie jeszcze mniejszych jednostkach czasu, powstawałoby w ogóle pytanie, czy celowe byłoby powoływanie do życia tego rodzaju reżimu ochronnego, który szatkując domenę publiczną, kolejną regulacją wyjmuje z niej na tak krótki okres pewną daną. Z pewnością ucierpiałaby w takiej sytuacji elementarna pewność prawna. 
economy, niem. Datenwirtschaft) zależy właśnie od możliwie szerokiego dostępu do jak największych zasobów danych.

Brak regulacji prawnej tego zagadnienia pozostaje akurat z pewnością w najlepiej pojętym interesie naszego kraju, który nie osiągnął poziomu samowystarczalności w tym zakresie i znajduje się w gronie krajów, które charakteryzują się palącą potrzebą importu danych ${ }^{20}$.

\section{Zamiast prawa własności - ustalenie zasad dostępu}

W tej sytuacji postulat samodzielnego „prawa własności danych” powinien zostać zastąpiony postulatem nakreślenia ram wyznaczających prawo dostępu do danych.

Stanowisko to pozostaje w zgodzie z obserwacją ogólnej natury: dostrzegalne staje się przesterowanie torów rozwoju gospodarki światowej opartej na dobrach objętych „świętym” prawem własności na dobra „współdzielone” pomiędzy wiele podmiotów. Jest to zjawisko typowe dla tzw. ery dostępu $\left(\right.$ Age of Access $\left.{ }^{21}\right)$. Innymi słowy, zamiast objęcia danych prawem wykluczającym podmioty trzecie z możliwości korzystania z nich, racjonalniejsze jest pochylenie się nad wypracowaniem zasad dostępu do zasobów danych. Ponieważ z uwagi na różnorodzajowość danych $^{22}$ nie jest wyobrażalne wypracowanie jednego zestawu zasad dostępu, niezbędne jest zróżnicowanie zasad w zależności od konkretnego sektora.

Branżowe przykłady mechanizmów dostępu do danych już istnieją. Dla przykładu, art. 7 ust. 1 rozporządzenia (WE) nr 715/2007 w sprawie homologacji pojazdów silnikowych przewiduje, że producenci pojazdów: moga pobierać opłaty w uzasadnionej i proporcjonalnej wysokości za dostęp do informacji dotyczacych naprawy i utrzymania pojazdów, objętych niniejszym rozporządzeniem. Przyznanie dostępu do danych powinno następować w szczególności w takich sytuacjach, które są uzasadnione „wyższym dobrem”. Innym przykładem w tym zakresie jest rozporządzenie (WE) 1907/2006, które ustanawia i promuje dostęp do wyników badań, jeśli dotyczą one testów prowadzonych na żywych zwierzętach - w oczywistym celu uniknięcia potrzeby przeprowadzania powtórnych badań.

20 Zob. też: D. Flisak, Status prawny danych nieosobowych: o braku zasadności stworzenia prawa własności i potrzebie ustalenia branżowych zasad dostępu do danych [w:] Założenia do strategii AI $w$ Polsce. Plan działań Ministerstwa Cyfryzacji, Warszawa, 9 listopada 2018 r., s. 154 i nast., https://www.gov.pl/documents/31305/436699/ Za\%C5\%82o\%C5\%BCenia_do_strategii_AI_w_Polsce_-_raport.pdf/a03eb166-0ce5-e53c-52a4-3bfb903edf0a [dostęp 25 kwietnia 2019 r.].

21 Pojęcie pochodzi od tytułu książki J. Rifkina, The Age of Access: The New Culture of Hypercapitalism, Where all of Life is a Paid-For Experience, New York 2001.

22 Trudno jest przecież - dla przykładu - znaleźć wspólny mianownik między danymi geolokalizacyjnymi właścicieli poszczególnych telefonów komórkowych z jednej strony, a zanieczyszczeniem wód Polski południowo-zachodniej. 


\section{Interakcja między rozwojem technicznym a procesem stanowienia prawa - przykłady}

\section{Dyrektywa w sprawie praw autorskich na jednolitym rynku cyfrowym - uwagi ogólne}

Klasycznym przykładem interakcji między rozwojem technologicznym a procesem stanowienia prawa jest dyrektywa w sprawie praw autorskich na jednolitym rynku cyfrowym ${ }^{23}$. Sama dyrektywa zwraca uwage już na poziomie swoich zapisów: preambuła ma bezprecedensowe rozmiary i została napisana zawiłym językiem. Nawet jeśli poziom skomplikowania materii, którą reguluje, mógł się również do tego przyczynić, widać, że jej treść była przedmiotem licznych poprawek i zmian. Ścierały się ze sobą dwa środowiska - zwolenników interesów pośredników internetowych oraz branży wydawniczej, jak i tych, którzy dążą do maksymalnego „uwolnienia” wszelkich treści internetowych ${ }^{24}$.

Przyczyny podjęcia dyrektywy zostały wskazane w preambule:

Szybki rozwój technologii cyfrowych zmienia sposób, w jaki tworzy się, produkuje, rozpowszechnia $i$ eksploatuje utwory $i$ inne przedmioty objęte ochrona. Wciąż pojawiaja się nowe modele biznesowe i nowe podmioty. Odpowiednie przepisy ustawodawcze powinny uwzględniać przyszłe przemiany, aby nie ograniczać rozwoju technologicznego [...] Aby zapewnić prawidłowe i sprawiedliwe funkcjonowanie rynku prawa autorskiego, należy również wprowadzić zasady dotyczace praw w publikacjach i korzystania z utworów lub innych przedmiotów objętych ochrona przez dostawców usług internetowych polegajacych na przechowywaniu i udzielaniu dostępu do treści zamieszczanych przez użytkowników, zasady dotyczace transparentności umów z twórcami $i$ wykonawcami, wynagradzania twórców $i$ wykonawców, a także mechanizm odwołania praw, które twórcy i wykonawcy przenieśli na zasadzie wyłączności.

\section{Prawo pokrewne wydawców prasowych}

Dyrektywa wprowadza nowy rodzaj uprawnienia - prawo (pokrewne) wydawców prasowych od ich publikacji. Geneza samego uprawnienia jest dość prosta. Wydawcy prasowi od dawna sprzeciwiali się funkcjonowaniu w sieci internetowej tzw. agregatorów newsów, czyli serwisów, które zbierały w postaci hyperlinków wyimki z najświeższych publikacji prasowych. Nawet jeśli naciśnięcie

23 Zob. stanowisko Parlamentu Europejskiego przyjęte w pierwszym czytaniu w dniu 26 marca 2019 r. w celu przyjęcia dyrektywy Parlamentu Europejskiego i Rady (UE) 2019/ w sprawie prawa autorskiego i praw pokrewnych na jednolitym rynku cyfrowym oraz zmiany dyrektyw 96/9/WE i 2001/29/WE.

24 Zwanych również „otwartystami” - zob. np. S. Czubkowska, Batalia o prawa autorskie $w$ internecie: artyści kontra otwartyści, https://forsal.pl/artykuly/710214,batalia-o-prawa-autorskie-w-internecie-artysci-kontra-otwartysci.html [dostęp 25 kwietnia 2019 r.]. 
danego hyperlinka przenosiło internautę do pełnej wersji danego artykułu na stronie internetowej jego wydawcy, bywało i tak, że nie wszyscy użytkownicy decydowali się na lekturę całego artykułu na macierzystej stronie gazety. Wielu czytelników zadowalało się już samą treścią znajdującą się na stronie agregatora, czyli tytułem publikacji, ewentualnie wraz z krótkim wstępem. Tymczasem brak przejścia czytelnika na stronę internetową wydawcy pozbawiał tego ostatniego istotnego zysku w postaci „ruchu” (traffic) na własnej stronie internetowej, co z kolei odbijało się negatywnie na reklamowej wartości jego witryny internetowej (zgodnie z logiką, że większy ruch na stronie internetowej oznacza jej większą atrakcyjność dla potencjalnych reklamodawców).

Z powyższego wynika, że nowoczesne technologie umożliwiły podmiotom dysponującym zaawansowaną infrastrukturą teleinformatyczną wykształcenie się nowego modelu biznesowego, który - akurat w opisanym przypadku - bazował właściwie niemal całkowicie na wysiłku podmiotów trzecich (tj. wydawców prasowych; na marginesie, szacuje się, że ustanowienie nowego prawa przyniesie polskiej prasie ok. $50 \mathrm{mln}$ zł dodatkowych przychodów rocznie ${ }^{25}$ ).

Aby zapobiec temu chyba dość oczywistemu poszkodowaniu wydawców prasowych, niektóre kraje europejskie (Niemcy, Hiszpania) zdecydowały się na samodzielne uregulowanie tej kwestii poprzez - ujmując rzecz najogólniej - zobowiązanie operatorów agregatorów (w istocie chodziło o wyszukiwarkę Google, stąd nazwa tej regulacji google lex) do uiszczania wynagrodzenia z tytułu korzystania z publikacji prasowych. Dość szybko okazało się jednak, że amerykański potentat jako faktyczny monopolista nie tylko nie uiścił spodziewanego wynagrodzenia, ale wyłączył bądź zagroził wyłączeniem publikacji wydawców prasowych z wyników swojej wyszukiwarki. Ziszczenie się takiego scenariusza (jak nastąpiło to w Hiszpanii) okazało się katastrofalne w skutkach właśnie dla samych wydawców prasowych, którzy dodatkowo istotnie stracili na „ruchu” na własnych stronach internetowych. Obecnie strona niemiecka zarzuciła operatorowi wyszukiwarki przed niemieckimi sądami łamanie praw autorskich oraz nadużywanie pozycji monopolistycznej. Dodatkowo Trybunał Sprawiedliwości UE zbada, czy Niemcy przed wprowadzeniem u siebie nowego prawa powinni byli notyfikować tę zmianę w Komisji Europejskiej i czy to zrobili. W przypadku korzystnych dla wydawców prasowych rozstrzygnięć wartość sporu szacuje się na kolosalną kwotę 1,8 mld euro ${ }^{26}$.

25 A. Słojewska, P. Mazurkiewicz, Parlament Europejski przyją dyrektywe o prawach autorskich, „Rzeczpospolita” z 27 marca 2019 r., https:/www.rp.pl/Prawo-autorskie/303269912-Parlament-Europejski-przyjal-dyrektywe-o-prawach-autorskich.html [dostęp 25 kwietnia 2019 r.].

26 J. Wojtaś, Dyrektywa autorska: korzyści dla wydawców, „Rzeczpospolita” z 12 kwietnia 2019 r., https://www.rp.pl/Prawo-autorskie/304129975-Dyrektywa-autorska-korzysci-dla-wydawcow.html [dostęp 25 kwietnia 2019 r.]. 
Mimo tych doświadczeń we wprowadzaniu nowego prawa przegłosowana pod koniec marca 2019 r. dyrektywa w sprawie praw autorskich na jednolitym rynku cyfrowym, mało fortunnie określana jako „ACTA II”, zawiera podobną regulację mającą na celu ochronę publikacji prasowych w zakresie sposobów korzystania online ${ }^{27}$. Można założyć, że brukselski ustawodawca przyjął, iż siła wszystkich krajów unijnych, które będą musiały dokonać implementacji zapisów dyrektywy (a zatem również i nowego prawa chroniącego interesy wydawców prasowych), w zderzeniu $\mathrm{z}$ obecnymi hegemonami rynku internetowego, jak operator Google, będzie zdecydowanie większa niż wysiłki pojedynczych krajów, choćby z bardzo silną pozycją prasy (jak ma to miejsce w Niemczech). To założenie jest również charakterystyczne dla obecnych procesów stanowienia prawa: wskutek faktycznego zniknięcia granic prawdziwie istotne regulacje prawne mogą i powinny być ustanawiane na płaszczyźnie międzynarodowej - czy to unijnej, czy wręcz ogólnoświatowej.

\section{Sytuacja prawna dostawców treści online}

Sama dyrektywa jest ciekawym i symptomatycznym przykładem legislacji czasów nowych technologii. Jej twórcy postawili sobie ambitne zadanie regulacji zjawisk, które $\mathrm{w}$ prostej linii są wynikiem konsekwencji powstania nowych technologii. Prócz zasygnalizowanej kwestii korzystania z publikacji prasowych, chodziło także, a może przede wszystkim, o zwrócenie uwagi na nowe modele komercjalizacji treści w internecie. Ów model polega na ich dostarczaniu platformom internetowym (Youtube, Twitter, Facebook etc.) - pośrednikom w kontakcie z konsumentami dóbr intelektualnych, którzy następnie doprowadzają do ich rozpowszechnienia. Ponieważ to właśnie owi pośrednicy czerpią najwięcej korzyści z rozpowszechnianych treści, podstawowym zamierzeniem autorów dyrektywy było wymuszenie podziału tych korzyści z ich rzeczywistymi „producentami" (profesjonalnymi, ale i również zwykłymi internautami).

$\mathrm{Z}$ uwagi na powyższe największe praktyczne znaczenie należy przypisać regulacji dotyczącej dostawców treści online (art. 17 dyrektywy) ${ }^{28}$. Jako zasadę wska-

27 Art. 15 ust. 1 dyrektywy w sprawie praw autorskich na jednolitym rynku cyfrowym: Państwa członkowskie zapewniaja wydawcom publikacji prasowych mającym siedzibe $w$ danym państwie członkowskim prawa przewidziane $w$ art. 2 i art. 3 ust. 2 dyrektywy 2001/29/WE $w$ zakresie sposobów korzystania online $z$ ich publikacji prasowych przez dostawców usług społeczeństwa informacyjnego. Prawa określone $w$ akapicie pierwszym nie maja zastosowania do prywatnych i niekomercyjnych sposobów korzystania z publikacji prasowych przez użytkowników indywidualnych. Ochrona zagwarantowana $w$ pierwszym akapicie nie ma zastosowania do czynności linkowania. Prawa określone $w$ akapicie pierwszym nie mają zastosowania do pojedynczych słów lub bardzo krótkich fragmentów publikacji prasowej.

28 Art. 17 ust. 1 dyrektywy: Państwa członkowskie wprowadzaja przepisy przewidujace, że dostawca usług udostępniania treści online dokonuje czynności publicznego 
zano, że serwisy internetowe (typu Youtube, Twitter) mogą rozpowszechniać składowane (uploadowane) na nich treści pod warunkiem uprzedniego uzyskania zezwolenia. Można sobie łatwo wyobrazić, że uzyskanie takiego zezwolenia nie powinno być problematyczne w przypadku treści pochodzących od podmiotów działających profesjonalnie, np. producentów filmów czy piosenek. Jednocześnie w przypadku kontentu (ang. content) pochodzącego od innych, nazwijmy ich, „nieprofesjonalnych” internautów (tzw. user generated content), trudno wyobrazić sobie, w jaki sposób obowiązek uprzedniego nawiązania kontaktu miałby być realizowany. Dobrym przykładem jest prawdziwa sól twórczości internautów - memy internetowe ${ }^{29}$, których istota zasadza się przecież na czerpaniu z cudzych utworów poprzez ich śmieszną, parodystyczną, a co najmniej zastanawiającą transformację. Memy internetowe są immanentną częścią funkcjonowania najbardziej aktywnych internautów w sieci internetowej, naturalną formą komunikacji młodego pokolenia, które w przyszłości będzie przecież wyznaczać kierunek rozwoju sieci internetowej. Wskutek braku realnej możliwości nawiązania kontaktu z autorami owych memów (liczonych przecież w milionach), siłą rzeczy będą one poddawane automatycznemu odfiltrowaniu (blokowaniu) przez wskazanych dostawców. Jaki interes mieliby mieć ci ostatni w tym, aby narażać się na ryzyko odpowiedzialności prawnej? Czy jest prawdopodobne, aby każdy z dostarczonych na platformę memów był starannie oceniany, czy stanowi on satyrę, karykaturę bądź parodię $e^{30}$ ? Odpowiedź na te pytania nie jest oczywista. Nawet jeśli dyrektywa w wielu miejscach zobowiązuje do respektowania działań internautów korzystających z przywilejów cytowania, krytyki, karykatury, pastiszu czy parodii, nie widać sprawnej metody realizowania tego zobowiązania. W ostatecznym rezultacie można się obawiać, że art. 17 może być realizowany ze szkodą dla user generated content, a ewentualna poprawa losu profesjonalnych artystów nastąpi kosztem najważniejszej dla rozwoju kultury grupy „pospolitych” internautów.

udostępniania lub czynności podawania do publicznej wiadomości do celów niniejszej dyrektywy, w przypadku gdy udziela on publicznego dostępu do chronionych prawem autorskim utworów lub innych przedmiotów objętych ochrona zamieszczanych przez jego użytkowników. Dostawca usług udostępniania treści online musi zatem uzyskać zezwolenie od podmiotów uprawnionych, o którym mowa w art. 3 ust. 1 i 2 dyrektywy 2001/29/WE, na przykład poprzez zawarcie umowy licencyjnej, w celu publicznego udostępniania lub podawania do publicznej wiadomości utworów lub innych przedmiotów objetych ochrona.

29 Mem internetowy - gatunek wypowiedzi internetowej, komunikat obrazkowy zbudowany według schematu konstrukcyjnego wykorzystującego skonwencjonalizowane elementy związane z kulturą i historią, za: https://pl.wikipedia.org/wiki/Mem_internetowy [dostęp 25 kwietnia 2019 r.].

30 Wówczas nie byłaby wymagana zgoda podmiotu uprawnionego do memów. 


\section{Zastosowane najnowszych technologii w postępowaniach sądowych}

Wzajemne oddziaływanie pomiędzy stanowieniem prawa a najnowszymi technologiami można również prześledzić na przykładzie postępującej informatyzacji postępowania sądowego.

\section{Systemy analizy prawa}

Choć istnieje wiele aspektów stosowania najnowszych technologii w judykatu$\mathrm{rze}^{31}$, ramy niniejszego opracowania pozwalają na przyjrzenie się ledwie kilku wybranym sposobom wykorzystania sztucznej inteligencji (lub lepiej: deep learning systems - „systemów głęboko uczących się”) ${ }^{32}$. Mowa o systemach wyszukiwania informacji prawnej (legal retrieval systems) oraz o systemach analizy prawa (legal analysis systems). Jeśli idzie o te pierwsze, na rodzimym rynku prawniczym już istnieją zaawansowane systemy informacji prawnej dystrybuowane przede wszystkim przez dwa olbrzymie wydawnictwa ${ }^{33}$. Do grupy systemów analizy prawa należą z kolei tzw. systemy eksperckie (legal expert systems), które mogą znakomicie wspierać pracę sędziów czy - ogólniej - prawników poprzez "podpowiadanie” im optymalnego rozwiązania sprawy czy to na bazie uprzednio zdefiniowanych reguł (tzw. rule-based systems), czy też poprzednich rozstrzygnięć sądowych (tzw. case-based systems) ${ }^{34}$. Warto podkreślić, że w podstawowym portalu polskiego orzecznictwa na stronie internetowej orzeczenia.ms.gov. pl znajduje się obecnie już niemal 300 tys. orzeczeń sądowych ${ }^{35}$, które stanowią świetny materiał dla eksploracji danych.

Przy okazji warto jednak wskazać na pewne uniwersalne niebezpieczeństwo wynikające z zastosowania w praktyce „inteligentnych” systemów komputero-

31 Zob. np. Ł. Goździaszek, Perspektywy wykorzystania sztucznej inteligencji w postępowaniu sądowym, „Przegląd Sądowy” 2015, nr 10, s. 46 i nast.

32 Perspektywa zastosowania w sądownictwie elektronicznego sędziego - tzw. maszyny wyrokującej (judgment machine) jest wciąż raczej domeną fantastycznych filmów fabularnych, zob. B. Alarie, A. Niblett, A. Yoon, How Artificial Intelligence Will Affect the Practice of Law, https://papers.ssrn.com/sol3/papers.cfm?abstract_id=3066816 [dostęp 25 kwietnia 2019 r.].

33 A. Bieliński, Potencjalne obszary zastosowania sztucznej inteligencji w postępowaniu cywilnym - czy obecnie ma to rację bytu i czy jesteśmy na takie rozwiązanie gotowi? [w:] Sztuczna inteligencja, blockchain, cyberbezpieczeństwo oraz dane osobowe, red. K. Flaga-Gieruszyńska, J. Gołaczyński, D. Szostek, Warszawa 2019, s. 62 i nast.

34 Możliwe jest również połączenie obu rodzajów systemów eksperckich (tzw. hybrid systems) - zob. Ł. Goździaszek, Perspektywy wykorzystania sztucznej inteligencji, op. cit., s. 49 i nast.

35 W dniu 30 marca 2019 r. zawartość portalu stanowiły 295194 orzeczenia sądowe. 
wych. Chodzi mianowicie o ryzyko powtarzania (replikacji) zachowań o charakterze dyskryminacyjnym:

Obecnie sztuczna inteligencja jest rozwijana w jednorodnym środowisku złożonym przeważnie z młodych, białych mężczyzn, przez co wpisuje się w niq (świadomie czy nie) różnice kulturowe i związane z płcia społeczno-kulturowa, między innymi dlatego, że systemy sztucznej inteligencji ucza się na podstawie danych treningowych. Dane te musza być prawidłowe, a także cechować się wysoka jakościa $i$ bezstronnościq oraz być zróżnicowane i wystarczająco gruntowne. Powszechnie sądzi się, że dane sa $z$ definicji obiektywne, jest to jednak mylne wyobrażenie. Łatwo jest nimi manipulować, moga być tendencyjne, odzwierciedlać uprzedzenia i preferencje kulturowe, płciowe i inne ${ }^{36}$.

W przypadku całkowitego oparcia podejmowanych decyzji na algorytmach programów komputerowych, które - jak każde oprogramowanie komputerowe może odzwierciedlać własne, najszerzej rozumiane, preferencje czy poglądy ich twórców, może dochodzić do utrwalania dyskryminacyjnych trendów bądź linii orzeczniczej. Możliwym do wyobrażenia przykładem takich sytuacji jest dyskryminacyjne traktowanie osób określonej proweniencji, o określonym kolorze skóry, zamieszkałych na określonym terytorium czy o określonym światopoglądzie.

\section{Automatyzacja postępowań sądowych}

Zaawansowana digitalizacja oraz cyfryzacja umożliwiają już nie tylko obecnie funkcjonujące ułatwienia w procedowaniu sądowym nad sprawami (e-protokół, e-uzasadnienia), lecz również pełną automatyzację prostszych (powtarzalnych) postępowań sądowych, np. wieczystoksięgowych czy rejestrowych ${ }^{37}$. Dla przykładu, art. 8 rozporządzenia (WE) nr 1896/2006 z 12 grudnia 2006 r. ustanawiającego postępowanie w sprawie europejskiego nakazu zapłaty przewiduje już możliwość automatycznego przetwarzania danych (an automated procedure) w sprawach o wydanie europejskich nakazów zapłaty. Do tej pory nie skorzystano w naszym kraju z tej możliwości, choć wydaje się, że Konstytucja RP nie stanowi przeszkody w zastosowaniu zautomatyzowanych metod rozstrzygania spraw sądowych ${ }^{38}$.

Jedną z podstawowych korzyści z wprowadzenia automatyzacji jest szybkość. Warto sobie uświadomić, że akurat ta cecha jest już realizowana w przypadku rozstrzygnięć zapadłych $\mathrm{w}$ ramach elektronicznego postępowania upominaw-

36 Opinia Europejskiego Komitetu Ekonomiczno-Społecznego, Sztuczna inteligencja: wpływ sztucznej inteligencji na jednolity rynek (cyfrowy), produkcje, konsumpcje, zatrudnienie i społeczeństwo (2017/C 288/01), s. C288/4.

37 A. Bieliński, Potencjalne obszary zastosowania sztucznej inteligencji, op. cit., s. 64.

38 Zob. A. Kościółek, Wykorzystanie sztucznej inteligencji w sądowym postępowaniu cywilnym - zagadnienia wybrane [w:] Sztuczna inteligencja, blockchain, cyberbezpieczeństwo oraz dane osobowe, red. K. Flaga-Gieruszyńska, J. Gołaczyński, D. Szostek, Warszawa 2019, s. 73. 
czego $^{39}$, które jest stosowane w sprawach pozbawionych kontrowersji. Zgodnie z przeprowadzonymi obliczeniami sędziowie oraz referendarze sądowi orzekający w tych sprawach wydają ok. 250 decyzji dziennie. Mając na uwadze ośmiogodzinny wymiar pracy, oznacza to, że średni czas wydania decyzji musi wynosić jedynie niecałe 2 minuty ${ }^{40}$.

\section{Dowody cyfrowe}

Kolejnym aspektem powiązania prawa $\mathrm{z}$ technologią jest zagadnienie korzystania $\mathrm{w}$ postępowaniach sądowych $\mathrm{z}$ dowodów elektronicznych (nazywanych również dowodami cyfrowymi). Ponieważ istnieje olbrzymia luka w zakresie technologicznych zasad postępowania z dowodami elektronicznymi ${ }^{41}$, Rada Europy zdecydowała się na wypracowanie wytycznych, które choć mają niewiążący prawnie charakter są niezwykle przydatnym narzędziem (toolbox). Mają one ułatwiać sądom korzystanie z e-dowodów, które mogą przybrać postać wiadomości emailowych, plików wideo, zdjęć czy dźwiękowych nagrań pochodzących z komputerów, stron internetowych, telefonów komórkowych czy przechowywanych choćby w chmurze obliczeniowej (cloud computing). Dowody cyfrowe mogą być również przydatne w sporach o charakterze transgranicznym, których liczba będzie najprawdopodobniej lawinowo rosnąć, choćby z uwagi na globalny charakter sieci internetowej bądź upowszechnienie usługi przechowywania danych w chmurach obliczeniowych (cloud computing).

Jedną z podstawowych zasad przyjętych przez Radę Europy jest respektowanie zasady neutralności technologicznej, wedle której dowody cyfrowe nie powinny być ani uprzywilejowane, ani też dyskryminowane w porównaniu $\mathrm{z}$ innymi środkami dowodowymi ${ }^{42}$. Wytyczne zalecają akceptację wszelkich dowodów cyfrowych, o ile co innego nie wynika z prawa określonego kraju. Jednocześnie w przypadku kwestionowania przez stronę jakiegoś e-dowodu, strona przeciwna powinna zostać zobowiązana do wykazania jego wiarygodności.

Technologią szczególnie gwarantującą autentyczności dowodów jest blockchain - rozproszona i współdzielona baza danych, działająca wedle określonego protokołu. Technologia ta, choć już znana od dekady, wciąż nie może się przebić do powszechnego użytku mimo posiadania unikalnego waloru - wiarygodności zapisanych danych z uwagi na odporność na ich modyfikację. Upraszczając

39 Zob. art. 505(28)-505(39) Kodeksu postępowania cywilnego.

40 Za: M. Siemaszkiewicz, Automatyzacja postępowania cywilnego - zagadnienia wybrane, „Prawo Mediów Elektronicznych” 2017, nr 1, s. 42; zob. też: Ł. Goździaszek, Perspektywy wykorzystania sztucznej inteligencji, op. cit., s. 56.

${ }_{41}$ M. Świerczyński, Wytyczne Rady Europy w sprawie dowodów elektronicznych w postępowaniach cywilnych i administracyjnych - komentarz konsultanta [w:] Sztuczna inteligencja, blockchain, cyberbezpieczeństwo oraz dane osobowe, red. K. Flaga-Gieruszyńska, J. Gołaczyński, D. Szostek, Warszawa 2019, s. 171-182, passim.

42 Ibidem, s. 175 i nast. 
tę skomplikowaną kwestię, można powiedzieć, że niezmienność i integralność danych wynika z faktu, że blockchain stanowi zestawienie rekordów (bloków) z określoną treścią, które są wzajemnie połączone oraz zabezpieczone kryptograficznie. Zmiana zapisu jednego rekordu wymagałaby tożsamej zmiany w innych blokach połączonych w jeden łańcuch. Choć samo pojęcie blockchaina nie zostało ujęte w wytycznych, towarzyszący im oficjalny komentarz (tzw. explanatory memorandum) zwraca uwagę na przydatność tej technologii w omawianej materii powiązanej z dowodami cyfrowymi ${ }^{43}$.

\section{Podsumowanie}

Wpływ najnowszych technologii na proces stanowienia prawa jest niewątpliwy i wraz z postępującym upowszechnianiem się fenomenów technologicznych (sztucznej inteligencji, internetu rzeczy, olbrzymich zbiorów danych) będzie się stawał coraz większy. Istotne w procesie stanowienia prawa jest to, aby to ustawodawca adaptował przepisy do naturalnych zachowań w społeczeństwie informacyjnym. Odwrotna sytuacja, kiedy to ustawodawca usiłuje regulować procesy rynkowe, musi skutkować niepowodzeniem.

Rozwój nowoczesnych technologii przyczynia się również do zmiany dotychczasowych modeli biznesowych oraz zachowań konsumenckich - projekt dyrektywy w sprawie praw autorskich na jednolitym rynku cyfrowym dowodzi trudności w prawnym regulowaniu tych zjawisk. Z kolei przykład regulacji statusu prawnego danych maszynowych dowodzi, że bezrefleksyjne ustanowienie kolejnego prawa wyłącznego może mieć fatalne skutki dla innowacyjności.

\section{Bibliografia}

Alarie B., Niblett A., Yoon A., How Artificial Intelligence Will Affect the Practice of Law, https://doi.org/10.2139/ssrn.3066816.

Bieliński A., Potencjalne obszary zastosowania sztucznej inteligencji w postepowaniu cywilnym - czy obecnie ma to rację bytu i czy jesteśmy na takie rozwiązanie gotowi? [w:] Sztuczna inteligencja, blockchain, cyberbezpieczeństwo oraz dane osobowe, red. K. Flaga-Gieruszyńska, J. Gołaczyński, D. Szostek, Warszawa 2019.

Chałubińska-Jentkiewicz K., Karpiuk M., Prawo nowych technologii, 2015, LEX.

43 Zob. też: J. Szczerbowski, Problematyka udowodnienia faktów przy pomocy zapisów na łańcuchu bloków (blockchain) w postępowaniu cywilnym [w:] Dowody w postępowaniach sadowych, red. T. Gardocka, D. Jagiełło, 2018, Legalis. 
Czubkowska S., Batalia o prawa autorskie w internecie: artyści kontra otwartyści, https:// forsal.pl/artykuly/710214,batalia-o-prawa-autorskie-w-internecie-artysci-kontra-otwartysci.html.

Flisak D., Status prawny danych nieosobowych: o braku zasadności stworzenia prawa własności i potrzebie ustalenia branżowych zasad dostępu do danych [w:] Założenia do strategii AI w Polsce. Plan działań Ministerstwa Cyfryzacji, Warszawa, 9 listopada 2018 r.

Goździaszek Ł., Perspektywy wykorzystania sztucznej inteligencji w postępowaniu sądowym, „Przegląd Sądowy” 2015, nr 10.

Hilty R., Eine neue Kultur, „Süddeutsche Zeitung” z 20 marca 2019 r.

Hugenholtz B., Data Property: Unwelcome Guest in the House of IP, https://www.ivir.nl/ publicaties/download/Data_property_Muenster.pdf.

Kerber W., A New (Intellectual) Property Right for Non-Personal Data? An Economic Analysis, https://papers.ssrn.com/sol3/papers.cfm?abstract_id=2858171.

Kościółek A., Wykorzystanie sztucznej inteligencji w sądowym postępowaniu cywilnym zagadnienia wybrane [w:] Sztuczna inteligencja, blockchain, cyberbezpieczeństwo oraz dane osobowe, red. K. Flaga-Gieruszyńska, J. Gołaczyński, D. Szostek, Warszawa 2019.

Osowski D., Historia bitcoina. Kryptowaluta świętuje 10. urodziny, „Parkiet” z 31 października 2018 r.

Rifkin J., The Age of Access: The New Culture of Hypercapitalism, Where all of Life is a Paid-For Experience, New York 2001.

Rojszczak M., Prawne aspekty systemów sztucznej inteligencji - zarys problemu [w:] Sztuczna inteligencja, blockchain, cyberbezpieczeństwo oraz dane osobowe, red. K. Flaga-Gieruszyńska, J. Gołaczyński, D. Szostek, Warszawa 2019.

Sawczuk M., Tradycja a postęp [w:] Ewolucja polskiego postępowania cywilnego wobec przemian politycznych, społecznych i gospodarczych, red. H. Dolecki, K. Flaga-Gieruszyńska, Warszawa 2008.

Siemaszkiewicz M., Automatyzacja postępowania cywilnego - zagadnienia wybrane, „Prawo Mediów Elektronicznych" 2017, nr 1.

Słojewska A., Mazurkiewicz P., Parlament Europejski przyjąt dyrektywe o prawach autorskich, „Rzeczpospolita” z 27 marca 2019 r.

Szczerbowski J., Problematyka udowodnienia faktów przy pomocy zapisów na łańcuchu bloków (blockchain) w postępowaniu cywilnym [w:] Dowody w postępowaniach sądowych, red. T. Gardocka, D. Jagiełł, 2018, Legalis.

Świerczyński M., Wytyczne Rady Europy w sprawie dowodów elektronicznych w postępowaniach cywilnych i administracyjnych - komentarz konsultanta [w:] Sztuczna inteligencja, blockchain, cyberbezpieczeństwo oraz dane osobowe, red. K. Flaga-Gieruszyńska, J. Gołaczyński, D. Szostek, Warszawa 2019.

Wojtaś J., Dyrektywa autorska: korzyści dla wydawców, „Rzeczpospolita” z 12 kwietnia $2019 \mathrm{r}$.

Yu P.K., Data Producer's Right and the Protection of Machine-Generated Data, "Tulane Law Review” 2019, Vol. 93. 